\title{
Production and Characterization of Keratinolytic Protease from New Wool-Degrading Bacillus Species Isolated from Egyptian Ecosystem
}

\author{
Mohamed A. Hassan, ${ }^{1}$ Bakry M. Haroun, ${ }^{2}$ Amro A. Amara, ${ }^{1}$ and Ehab A. Serour ${ }^{1,3}$ \\ ${ }^{1}$ Protein Research Department, Genetic Engineering and Biotechnology Research Institute, \\ City of Scientific Research and Technological Applications, New Borg Al-Arab, P.O. Box. 21934, Alexandria, Egypt \\ ${ }^{2}$ Botany and Microbiology Department, Faculty of Science (Boys), Al-Azhar University, Cairo, Egypt \\ ${ }^{3}$ King Abdulaziz City for Science and Technology, Riyadh, Saudi Arabia \\ Correspondence should be addressed to Mohamed A. Hassan; m_adelmicro@yahoo.com
}

Received 2 December 2012; Revised 7 March 2013; Accepted 28 March 2013

Academic Editor: Periasamy Anbu

\begin{abstract}
Copyright ( 2013 Mohamed A. Hassan et al. This is an open access article distributed under the Creative Commons Attribution License, which permits unrestricted use, distribution, and reproduction in any medium, provided the original work is properly cited.

Novel keratin-degrading bacteria were isolated from sand soil samples collected from Minia Governorate, Egypt. In this study, the isolates were identified as Bacillus amyloliquefaciens MA20 and Bacillus subtilis MA21 based on morphological and biochemical characteristics as well as $16 \mathrm{~S}$ rRNA gene sequencing. B. amyloliquefaciens MA20 and B. subtilis MA21 produced alkaline keratinolytic serine protease when cultivated in mineral medium containing $1 \%$ of wool straight off sheep as sole carbon and nitrogen source. The two strains were observed to degrade wool completely to powder at $\mathrm{pH} 7$ and $37^{\circ} \mathrm{C}$ within 5 days. Under these conditions the maximum activity of proteases produced by B. amyloliquefaciens MA20 and B. subtilis MA21 was 922 and 814 U/ml, respectively. The proteases exhibited optimum temperature and $\mathrm{pH}$ at $60^{\circ} \mathrm{C}$ and 9 , respectively. However, the keratinolytic proteases were stable in broad range of temperature and $\mathrm{pH}$ values towards casein Hammerstein. Furthermore the protease inhibitor studies indicated that the produced proteases belong to serine protease because of their sensitivity to PMSF while they were inhibited partially in presence of EDTA. The two proteases are stable in most of the used organic solvents and enhanced by metals suggesting their potential use in biotechnological applications such as wool industry.
\end{abstract}

\section{Introduction}

Keratins are classified as fibrous proteins called scleroproteins that occur abundantly in epithelial cells. These proteins are insoluble in water, weak acid and alkali, and organic solvents and are insensitive to the attack of common proteolytic enzymes such as trypsin or pepsin [1]. The animal remains rich in $\alpha$-keratin such as animal skin, hair, claws, horns, and wools.

The important property of these proteins is the presence of high cystine content that differentiates keratins from other structural proteins such as collagen and elastin. Both a high cystine content as well as a high content of glycine, proline, serine, and acidic amino acids and a low content of lysine, histidine, and methionine (or their lack) as well as the absence of tryptophan are also characteristic of keratins [2, 3]. Numerous disulfide cystine bonds present in keratin to bind peptide chains and packed as $\alpha$-helices as in hair and wool or in $\beta$-sheet arrangements as in case of feathers. The disulfide linkage and the tight secondary structure of keratins make them difficult to be hydrolysed by common proteolytic enzymes [4].

The major problem of $\alpha$-keratin hydrolysis is the presence a high numbers of disulfide bonds that make it insoluble in nature and resistant to proteases hydrolysis [5]. Keratinolytic protease enzymes are spread in nature and elaborated by different groups of microorganisms that can be isolated from polluted area with keratin wastes [6]. A vast variety of Grampositive bacteria including Bacillus, Lysobacter, Nesternokia, 
Kocuria, and Microbacterium as well as a few strains of Gramnegative bacteria such as Xanthomonas, Stenotrophomonas, and Chryseobacterium are confined as keratin degraders [7$10]$. Most of keratin degrading bacteria belong to the genus of Bacillus [11].

The keratinous substrate such as feather and wool can be degraded in basal medium by microorganisms which are capable of utilize keratin as sole carbon and nitrogen source [12]. Keratinolytic proteases have broad substrate specificity where they have the ability to hydrolyze soluble protein such as casein, gelatin, and bovine serum albumin. Additionally, they can hydrolyze the insoluble protein including feather, silk, and wool [13]. Keratinolytic proteases mostly belong to serine or metalloproteases showing sequence similarity with subtilisin group of proteases $[14,15]$. In recent years, more demands to keratinolytic proteases are increasing due to their multitude in industrial applications such as the feed, fertilizer, detergent, and textile industries. The present study describes the isolation and identification of new Bacillus amyloliquefaciens MA20 and B. subtilis MA21 strains from Egyptian ecosystem that grow well on wool as sole carbon source. Moreover the two strains are able to degrade wool and their enzymes can be used to improve the wool quality. This paper includes full characterization of the keratinolytic protease which explains that the best environmental conditions can be used to improve the wool quality in industry.

\section{Materials and Methods}

2.1. Sample Collection. Different types of samples were collected from different Governorates of Egyptian ecosystem included Alexandria, Behera, Qaliubia, Mania, and Asiut. These fresh samples were varied such as soil, sand soil, humus, waste wool, and rhizosphere under olive trees. These samples were collected in sterile falcon tubes and transported to the microbiological lab in (City of Scientific Research and Technological Applications).

2.2. Strains Isolation. The bacterial strains were isolated by suspending $1 \mathrm{~g}$ of soil samples in a $10 \mathrm{~mL}$ sterile $0.85 \%(\mathrm{w} / \mathrm{v})$ saline solution and then treated for $20 \mathrm{~min}$ at $80^{\circ} \mathrm{C}$. This will enable the isolation of the spore-forming bacteria. LuriaBertani (LB) agar medium with $1 \%(\mathrm{w} / \mathrm{v})$ skim milk was used for their cultivation by spreading $0.1 \mathrm{~mL}$ of each $10^{-5}$ and $10^{-6}$ dilutions. The plates then were incubated for 24 hours at different temperatures $[4,16]$. The colonies which give clear zones formed by hydrolysis of skim milk were picked. Pure bacterial isolates were obtained by reculturing individual colonies several times on fresh LB agar medium to produce single colony from each.

2.3. Strains Selection. Twelve selected strains isolated according to the diameter of clear zone were cultured on medium containing $0.5 \mathrm{~g} \mathrm{NaCl}, 0.3 \mathrm{~g} \mathrm{~K}_{2} \mathrm{HPO}_{4}, 0.4 \mathrm{~g} \mathrm{K \textrm {KH } _ { 2 }} \mathrm{PO}_{4}$, and $10 \mathrm{~g}$ wool per liter; $\mathrm{pH} 7$ and incubated for 5 days at $37^{\circ} \mathrm{C}$. The wool was used as sole carbon and nitrogen source for detecting potent strains that have the ability to degrade the wool completely. Three strains degraded the wool and the supernatants of their culture were assayed on plate containing $1 \%$ gelatin powder which is soluble in phosphate buffer $\mathrm{pH} 7$. After determining the existence of the activity (by the clear zone of the supernatants), Bacillus sp. MA20 and Bacillus sp. MA21 were selected and preserved for further investigation.

2.4. Bacterial Identification. While the phenotypic characteristics and isolation method of the two selected isolates indicate that they are related to Bacillus group but further identification was conducted.

The strains identification are included the spore morphology, Gram stain, and motility. The morphological and physiological characteristics of the bacterial isolates were compared with the data from Bergey's Manual of Determinative Bacteriology [17].

2.5. Scanning of Bacillus sp. MA20 and Bacillus sp. MA21 by Scanning Electron Microscope. The bacterial smear was prepared by centrifuging the bacterial cultures at $12,000 \mathrm{rpm}$ for $20 \mathrm{~min}$. The pellets were washed 2 times by saline solution. The pellet was suspended in sterilized distilled $\mathrm{H}_{2} \mathrm{O}$. The bacterial film was prepared and fixed on glass slides till complete drying. The smear was coated with gold using sputter coater. The golden coated sample was scanned at $20 \mathrm{KV}$ acceleration voltages at room temperature.

\subsection{Genetic Identification and Differentiation}

2.6.1. DNA Extraction. The genomic DNA of Bacillus strains was isolated using modification method from Sambrook et al. [18].

\subsubsection{Identification by $16 S$ Ribosomal RNA (rRNA)}

PCR Amplification according to Sambrook et al. [18]. The PCR amplification reactions were performed in a total volume of $50 \mu \mathrm{L}$. Each reaction mixture contained the following solutions: $2 \mu \mathrm{L}$ of DNA ( $40 \mathrm{ng}$ ), $1 \mu \mathrm{L}$ of 10 pmol forwarded 16S-rRNA primer (5'-AAATGGAGGAAGGTGGGGAT$\left.3^{\prime}\right) ; 1 \mu \mathrm{L}$ of $10 \mathrm{pmol}$ reverse $16 \mathrm{~S}$ rRNA primer $\left(5^{\prime}\right.$ AGGAGGTGATCCAACCGCA- $\left.3^{\prime}\right) ; \quad 0.8 \mu \mathrm{L}$ of $12.5 \mathrm{mM}$ (dNTP's); $5 \mu \mathrm{L}$ of PCR buffer included $\mathrm{MgCl}_{2}$, and $0.2 \mu \mathrm{L}$ Taq polymerase (1 Unit) and water-free DNAse and RNAse were added up to $50 \mu \mathrm{L}$. The PCR apparatus was programmed as follows: 3 min denaturation at $95^{\circ} \mathrm{C}$, followed by 35 cycles that consisted of $1 \mathrm{~min}$ at $95^{\circ} \mathrm{C}, 1 \mathrm{~min}$ at $58^{\circ} \mathrm{C}$, and $1 \mathrm{~min}$ at $72^{\circ} \mathrm{C}$, and a final extension was $10 \mathrm{~min}$ at $72^{\circ} \mathrm{C}$. The products of the PCR amplification were analyzed by agarose gel electrophoresis (2\%).

2.6.3. PCR Cleanup and $16 S$ rRNA Sequencing. The PCR products were cleaned up for DNA sequencing following the method described by Sambrook et al. [18]. Automated DNA sequencing based on enzymatic chain terminator technique, developed by Sanger et al. [19], was carried out using 3130X DNA Sequencer (Genetic Analyzer, Applied Biosystems, Hitachi, Japan). 
2.6.4. Phylogenetic Analysis. Similarity analysis of the nucleotides was performed by BLAST searches against sequences available in GenBank. For phylogenetic tree construction, multiple sequences were obtained from GenBank and the alignments were performed using MEGA 5 software version $5.1[20]$.

2.7. Keratinolytic Protease Production. Bacillus sp. MA20 and Bacillus sp. MA21 were first inoculated in liquid LB medium to produce large amount of cells. After $18 \mathrm{hrs}$, the colony forming units $(\mathrm{CFU}) / \mathrm{mL}$ culture were $3 * 10^{6}$, and $2 \%$ volume of the liquid medium was transferred to the production medium using $250 \mathrm{~mL}$ flask containing $100 \mathrm{~mL}$ of the production medium. The production medium containing (w/v) $\mathrm{NaCl}, 0.5 \mathrm{~g} / \mathrm{L} ; \mathrm{K}_{2} \mathrm{HPO}_{4}, 0.3 \mathrm{~g} / \mathrm{L} ; \mathrm{KH}_{2} \mathrm{PO}_{4}, 0.4 \mathrm{~g} / \mathrm{L}$; wool, $10 \mathrm{~g} / \mathrm{L}$; and the $\mathrm{pH}$ was adjusted 7.0-7.2 using $2 \mathrm{~N}$ of $\mathrm{NaOH}$ and $\mathrm{HCl}$ [16]. The cultivated media were incubated at $37^{\circ} \mathrm{C}$ and $200 \mathrm{rpm}$ for 5 days. Culture supernatants were obtained by centrifugation at $12,000 \mathrm{rpm}$ and $4^{\circ} \mathrm{C}$ for $30 \mathrm{~min}$. The different supernatants which contain the crude enzymes were used in assay and analysis of enzymes.

\subsection{Enzymes Assay}

2.8.1. Detection of the Proteolytic Activity on Plates. The crude enzyme of Bacillus sp. MA20 and Bacillus sp. MA21 was screened for their proteolytic activity using agar well diffusion plate method described by Amara et al., after modification [21]. One gram of gelatin powder was suspended in $100 \mathrm{~mL}$ phosphate buffer $\mathrm{pH} 7$ and autoclaved. After sterilization, the soluble component was added to sterile water containing agar (18 gm agar/L). The suspension then stirred gently and distributed in Petri dishes $(25 \mathrm{~mL} / \mathrm{plate})$. After complete solidification of the agar on plates, wells were punched out of the agar, by using a clean sterile cork borer. The base of each hole was sealed with a drop of melted sterile water agar (15 g agar per liter $\mathrm{H}_{2} \mathrm{O}$ ) using sterile Pasteur pipette. Fifty $\mu \mathrm{L}$ of each bacterial supernatant was added to each well and preincubated at $4^{\circ} \mathrm{C}$ for $2 \mathrm{hrs}$ and then overnight incubated at different temperatures.

2.8.2. Visualization of the Enzyme Clear Zone. Coomassie blue $(0.25 \%, w / v)$ in methanol-acetic acid-water $5: 1: 4$ $(\mathrm{v} / \mathrm{v} / \mathrm{v})$ was used in plates staining to visualize the gelatin hydrolysis where $10 \mathrm{~mL}$ was added to each plate and incubated in room temperature for $15 \mathrm{~min}$ followed by removing the staining solution from the plates surfaces and washing gently by distilled water. Then the plates were destained using destining solution $(66 \mathrm{~mL}$ methanol, $20 \mathrm{~mL}$ acetic acid, and $114 \mathrm{~mL} \mathrm{H}_{2} \mathrm{O}_{\text {bidest }}$ ) for a suitable time [22]. Also extracellular protease detection was determined according to Vermelho et al., [23] with modification. Staining was performed with $0.1 \%$ amido black in methanol-acetic acid-water $30: 10: 60$ (v/v/v) for 5-20 min (according to the quality of amido black stain) at room temperature. Regions of enzyme activity were detected as clear areas, indicating that hydrolysis of the substrates has been occurred.

\subsubsection{Enzyme Assay Spectrophotometrically}

Preparation of Casein in Different Buffers with Different $p H$. Casein Hammarstein was weighted in a quantity of $0.325 \mathrm{~g}$ and dissolved in $50 \mathrm{~mL}$ of different buffers at different $\mathrm{pH}$. The mixture was dissolved by heating gently to $80-90^{\circ} \mathrm{C}$ without boiling in water bath according to Amara and Serour [24] or using hot plate with stirring for more accurate because casein is highly stick with the walls of the container. The following buffers were used:

(i) sodium phosphate, $\mathrm{pH}$ 6-7-8 (0.1 M)

(ii) glycine/ $\mathrm{NaOH}$ pH 9-10 (0.1 M)

(iii) sodium phosphate dibasic/ $\mathrm{NaOH}$ pH 11 (0.05 M)

(iv) $\mathrm{KCl} / \mathrm{NaOH}$ pH $12(0.2 \mathrm{M}$ ).

2.8.4. Optimum Temperature of the Enzymes. Ten $\mu \mathrm{L}$ of each supernatant which contains the crude enzyme was added to $490 \mu \mathrm{L}$ of the casein Hammarsten soluble in buffer $\mathrm{pH}$ 7. The enzymes-substrate mixture was incubated at different temperatures of $20,30,40,50,60,70$, and $80^{\circ} \mathrm{C}$ using water bath for $15 \mathrm{~min}$. After the incubation period the enzyme reaction stopped by adding $500 \mu \mathrm{L}$ of $10 \%$ trichloroacetic acid (TCA). The mixture was allowed to stand in ice for $10 \mathrm{~min}$ and then centrifuged at $13,000 \mathrm{rpm}$ for $10 \mathrm{~min}$. The absorbance of each sample was determined spectrophotometrically at $280 \mathrm{~nm}$ and their tyrosine content derived from the tyrosine standard curve which was carried out according to Amara and Serour [24] and the enzyme activity was determined as Unit/mL.

2.8.5. Optimum $p H$ of the Enzymes. Ten $\mu \mathrm{L}$ of each supernatant which contains the crude enzyme was added to the $490 \mu \mathrm{L}$ of the casein Hammarsten soluble in different $\mathrm{pH}$ values. The enzymes-substrate mixture was incubated at $60^{\circ} \mathrm{C}$ which acts as optimum temperature in a water bath for $15 \mathrm{~min}$. At the end of incubation period the enzyme reaction stopped by adding $500 \mu \mathrm{L}$ of $10 \%$ trichloroacetic acid (TCA). The mixture was allowed to stand in ice for $10 \mathrm{~min}$ and then centrifuged at 13,000 rpm for $10 \mathrm{~min}$. The absorbance of each sample was determined spectrophotometrically at $280 \mathrm{~nm}$ and their tyrosine content derived from the tyrosine standard curve and the enzyme activity determined as Unit $/ \mathrm{mL}$.

2.8.6. Confirmation of Optimum $p H$ and Temperature. The previous reaction was performed using casein Hammarsten soluble in Glycine/ $\mathrm{NaOH} \mathrm{pH}$ 9. The enzyme substrate mixture was incubated at various temperature of $20,30,40,50$, 60,70 and $80^{\circ} \mathrm{C}$ in water bath for $15 \mathrm{~min}$. The enzyme activity was calculated as mentioned previously.

2.8.7. The Optimized Enzymes Reaction. The optimized reaction is a mixing between $10 \mathrm{uL}$ of crude enzyme and $490 \mu \mathrm{L}$ of the casein Hammarsten soluble in Glycine/ $\mathrm{NaOH}$ pH 9. The mixture was incubated at $60^{\circ} \mathrm{C}$ in water bath for $15 \mathrm{~min}$. The reaction was stopped with $500 \mu \mathrm{L}$ of $10 \%$ TCA. The mixture was allowed to stand in ice for $10 \mathrm{~min}$ and then was 
centrifuged at 13,000 rpm for $10 \mathrm{~min}$. The enzyme activity was determined as mentioned above using tyrosine standard curve.

2.8.8. Thermal Stability. The thermostability was carried out by preincubating the crude enzyme solution at a temperature range of $4^{\circ} \mathrm{C}$ to $80^{\circ} \mathrm{C}$ for 0.0 to $24 \mathrm{hrs}$. The residual activity was measured with standard enzyme reaction. The control is enzyme reacted at zero time (consider as 100\%) [16].

2.8.9. $p H$ Stability. The $\mathrm{pH}$ stability was determined by preincubating the enzyme solution in buffers with different $\mathrm{pH}$ values (3-12) at room temperature from 0.0 to $48 \mathrm{hrs}$. The residual activity was measured with standard enzyme reaction. The control is enzyme reacted at zero time and considered as $100 \%$ [16]. The following buffers were used:

(i) citrate buffer pH 3-4-5-6 (0.1 M)

(ii) sodium phosphate $\mathrm{pH}$ 7-8 (0.1 M)

(iii) glycine/ $\mathrm{NaOH}$ pH 9-10 (0.1 M)

(iv) sodium phosphate dibasic/NaOH pH $11(0.05 \mathrm{M})$

(v) $\mathrm{KCl} / \mathrm{NaOH} \mathrm{pH} 12(0.2 \mathrm{M})$.

2.8.10. Effect of Inhibitors. The inhibitors were added to supernatants which contain the produced enzyme and were incubated for $30 \mathrm{~min}$ at $30^{\circ} \mathrm{C}$ before being tested for proteolytic activity. Protease inhibitors phenylmethanesulphonyl fluoride (PMSF), ethylenediaminetetraacetic acid (EDTA), $\beta$ mercaptoethanol, and the detergent sodium dodecyl sulfate (SDS) were used. The inhibitors stocks were prepared in distilled water except that PMSF was prepared by using isopropanol. The final concentrations of PMSF, EDTA, and $\beta$-Mercaptoethanol are $5 \mathrm{mM}$ and $1 \mathrm{mM}$ while SDS is $0.5 \%$ and $0.1 \%(\mathrm{w} / \mathrm{v})$. The control was enzyme mixed with distilled water instead of inhibitors. Control activity was considered to be $100 \%$ [25].

2.8.11. Effect of Metal Ions. The effect of metal ions on protease activity was investigated using two concentrations of $5 \mathrm{mM}$ and $10 \mathrm{mM}$ (final concentration). The metal stock solutions were prepared in distilled water and diluted to the appropriate concentrations. The enzyme solution was mixed with the different metal solutions and incubated for $30 \mathrm{~min}$ at $30^{\circ} \mathrm{C}$ before assay. A control was also included where the enzyme was mixed with distilled water instead of metal solution. Control activity was considered to be $100 \%$ [25]. $\mathrm{ZnCl}_{2}$, $\mathrm{MgCl}_{2}, \mathrm{CuSO}_{4}$, Urea, $\mathrm{HgCl}_{2}, \mathrm{CaCl}_{2}, \mathrm{BaCl}_{2}$, Guanidin $\mathrm{HCl}$, and $\mathrm{MnCl}_{2}$ were used.

2.8.12. Effect of Solvents. The effect of the different solvents (Methanol, Ethanol, DMSO, Isopropanol, Tween 20, and Triton X100) on protease activity was investigated using a concentration of $1 \%$ and $0.5 \%$ (final concentration) [25].

\subsection{First-Dimension Protein Electrophoresis}

2.9.1. Sodium Dodecyl Sulfate Polyacrylamid Gel Electrophoresis (SDS-PAGE). Characterization of proteins and evaluation of the protein enrichment process SDS-PAGE was performed in a discontinuous SDS-PAGE vertical slab gel electrophoresis apparatus as described by Laemmli [26]. Discontinuous SDSPAGE consisted of a stacking gel (5\%, w/v, pH 6.8) and a separating gel $(12 \%, \mathrm{w} / \mathrm{v}, \mathrm{pH} 8.8)$. The separating gel was prepared in a $1 \mathrm{~mm}$ slab gel $(10 \times 10 \mathrm{~cm})$.

2.10. Gel Staining Using Silver Stain. The gels were stained using silver nitrate staining methods as described by Blum et al. [27].

2.11. Zymogram for the Detection of Protease Activity Using $S D S-P A G E$. As above in the case of protease zymography using SDS PAGE and the separating gel concentration was $12 \%$. The samples were mixed with $5 \mathrm{X}$ sample buffer without $\beta$-mercaptoethanol and without boiling.

After running the gel at $80 \mathrm{~V}$ the SDS-PAGE gel was stripped off from the gel plate and soaked in $1 \%$ triton X100 for $2 \mathrm{hrs}$ to change the solution every 1 hour or in $2.5 \%$ triton X100 for $30 \mathrm{~min}$ for removing SDS and renaturating the enzymes.

The gel was washed three times with tape water and soaked in $1 \%$ gelatin powder solubilized in Glycine/ $\mathrm{NaOH}$ buffer $\mathrm{pH} 9$ for $90 \mathrm{~min}$ at $60^{\circ} \mathrm{C}$. The gel was washed with buffer for $10 \mathrm{~min}$ before staining.

Then the gel was stained with Coomassie blue stain for 2 hrs. After that the gel was destained till the active bands appear.

2.12. Zymogram for Detecting Protease Activity Using Native $P A G E$. The gel was carried out using all components of the SDS-PAGE and the same conditions but without SDS as well as the buffers described above. The samples were prepared by mixing with $5 \mathrm{X}$ sample buffer for native PAGE and without boiling. The gel was washed with tap water and soaked into $1 \%$ gelatin powder as mentioned previously. Then the gel was stained with Coomassie blue stain for $2 \mathrm{hrs}$. After that, the gel was destained till the active bands appear.

2.13. Two-Dimension Polyacrylamide Gel Electrophoresis (2D$P A G E$ ). First-dimension isoelectric focusing (IEF) was performed using Ettan IPGphor3 and the second-dimension SDS-PAGE was applied using vertical electrophoresis of Ettan DALTtwelve System. The experiment was carried out using the operation instruction of manufacturer (GE healthcare company). The gels were stained with Coomassie stain where Coomassie blue R-250 (0.02 g) in methanol-glacial acetic acid-distilled water $(10 \mathrm{~mL}, 5 \mathrm{~mL}$, and $100 \mathrm{~mL}$ resp. $)$ was used.

\section{Results and Discussion}

3.1. Strain Isolation. Microbial keratinolytic protease has been described for various biotechnological applications in food, detergent, textiles, and leather industries, and yet the 
growing demand for these enzymes necessitates the screening for novel keratinolytic microorganisms with potential applications [28, 29]. Keratinolytic protease has been described for several species of Bacillus [30, 31] due to the broad distribution of keratinase among these genera, and this study focused on keratinolytic protease production from them.

A total of 48 pure cultures of spore-forming bacteria were isolated and purified which obtained from different samples collected from Governorates of Egypt. All isolates were screened using selective method for Bacillus isolation. The proteolysis activities of all the isolates were detected using the plate test method containing LB agar medium with $1 \%(\mathrm{w} / \mathrm{v})$ skim milk. Among the isolates analyzed, 12 isolates exhibited proteolytic activity in which they had a halo diameter of fivefold longer than the colony diameter. All isolates have the proteolytic activity but do not have the ability to degrade wool, for that the twelve selected isolates were grown using a medium which contain (w/v) $\mathrm{NaCl}$, $0.5 \mathrm{~g} / \mathrm{L} ; \mathrm{K}_{2} \mathrm{HPO}_{4}, 0.3 \mathrm{~g} / \mathrm{L} ; \mathrm{KH}_{2} \mathrm{PO}_{4}, 0.4 \mathrm{~g} / \mathrm{L}$; wool, $10 \mathrm{~g} / \mathrm{L}$; and the $\mathrm{pH}$ was adjusted at 7.0-7.2 using $2 \mathrm{~N} \mathrm{NaOH}$ and $\mathrm{HCl}$. The flasks were incubated for 5 days until the wool has been completely degraded by some isolates. Three Bacillus isolates show the ability to degrade the wool and gained the names Bacillus sp. MA20, Bacillus sp. MA21, and Bacillus sp. MA10. In the last screening step, the obtained supernatants from the cultivation of three above Bacillus strains culture media were assayed using agar well diffusion in Petri dishes including gelatin powder plate which suspended in phosphate buffer pH 7 as in Figure 1. Bacillus sp. MA20 and Bacillus sp. MA21 were selected for studying the keratinolytic protease enzyme based on the diameter of clear zone (Figure 1). By refering to their isolation source, the two selected strains were found to be isolated from Minia Governorates. This method is simple but proves to be efficient for determining the best enzymeproducing isolates. Out of the three strains, the two which were given the best result have been subjected to further identification.

\subsection{Strains Identification}

3.2.1. Identification by Morphological and Biochemical Tests. The morphological and physiological characteristics of the isolated strains were compared with the data from Bergey's Manual of Determinative Bacteriology [17] who revealed that Bacillus sp. MA20 and Bacillus sp. MA21 are matching with those of $B$. subtilis group. In previous articles on taxonomy, species included in the $B$. subtilis group are the following: $B$. velezensis, $B$. atrophaeus, $B$. mojavensis, $B$. malacitensis, $B$. axarquiensis, $B$. nematocida, $B$. vallismortis, $B$. subtilis, and $B$. amyloliquefaciens [32-34].

The two strains are aerobic, motile, and Gram-positive rods. The smears of Bacillus sp. MA20 and Bacillus sp. MA21 were scanned by scanning electron microscope which indicates the bacterial size of the two Bacillus strains which was measured by slime view program software.

The results of biochemical tests of the Bacillus sp. MA20 and Bacillus sp. MA21 indicated that they are related to

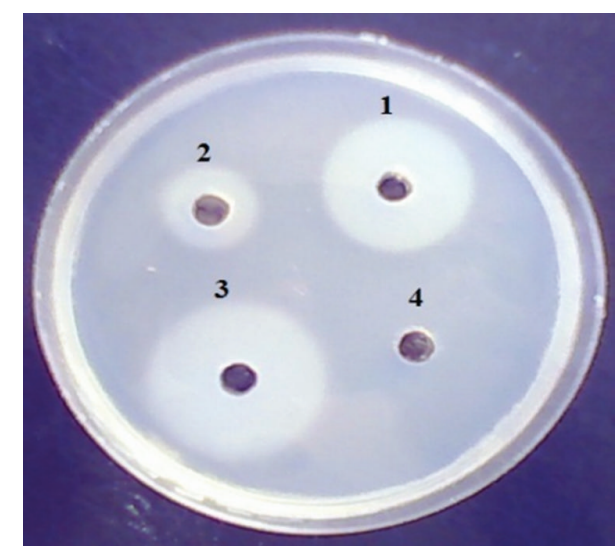

FIGURE 1: Proteolytic activity of the supernatants obtained from three Bacillus sp. on gelatin suspended in phosphate buffer $\mathrm{pH}$ 7. The well number (1) is supernatant from Bacillus sp. MA21, number (2) is from Bacillus sp. MA10, number (3) is from Bacillus sp. MA20, and (4) is control free of enzyme.

B. subtilis, and B. amyloliquefaciens which summarized in Table 1 .

\subsection{Identification Based on Genetic Materials (DNA)}

3.3.1. DNA Extraction. The isolated DNA was analyzed by gel electrophoresis and the quality of the DNA for each sample has been identified for further investigation.

3.3.2. Identification by $16 S$ Ribosomal RNA (rRNA). The amplified 16S rRNA gene from the DNA of Bacillus sp. MA20 and Bacillus sp. MA21 was determined using 2\% agarose gel. The size of the amplified fragments was determined by using size standard (Gene ruler $50 \mathrm{bp}-1031 \mathrm{bp}$ DNA ladder). The PCR products were visualized under UV light and photographed using gel documentation system. Approximately 380 bp of $16 S$ rRNA gene was amplified.

The PCR products were purified and sequenced using $16 \mathrm{~S}$ forward primer. The sequences of Bacillus sp. MA20 and Bacillus sp. MA21 were deposited in national center for biotechnology information (NCBI GenBank) under the Accession numbers (HQ115599.1-HQ115600.1), respectively. The basic local alignment search tool (BLAST) algorithm was used to retrieve for homologous sequences in GenBank.

The Bacillus sp. MA20 revealed 98\% identity to Bacillus amyloliquefaciens and Bacillus subtilis while Bacillus sp. MA21 revealed 97\% identity to Bacillus subtilis and Bacillus amyloliquefaciens. Based on the morphological, biochemical, and molecular characteristics, the Bacillus sp. MA20 and Bacillus sp. MA21 were designated as B. amyloliquefaciens MA20 and B. subtilis MA21, respectively.

A phylogenetic tree based on the comparison of $16 \mathrm{~S}$ rRNA sequences of reference strains was constructed. The phylogenetic analysis was performed with 341 bp sequences using the software MEGA 5 [20], using the neighbour-joining method and based on Jukes-Cantor distances. The branching 
TABLE 1: Morphological and biochemical properties of Bacillus sp. MA20 and Bacillus sp. MA21.

\begin{tabular}{|c|c|c|}
\hline Characteristics & Bacillus sp. MA20 & Bacillus sp. MA21 \\
\hline \multicolumn{3}{|l|}{ Morphological } \\
\hline Shape & Rods & Rods \\
\hline Gram stain & G+ve & G+ve \\
\hline Motility & Motile & Motile \\
\hline spore formation & +ve & +ve \\
\hline \multicolumn{3}{|l|}{ Growth } \\
\hline Growth temperature & $15^{\circ} \mathrm{C}-50^{\circ} \mathrm{C}$ & $15^{\circ} \mathrm{C}-60^{\circ} \mathrm{C}$ \\
\hline Growth pH & $5-8$ & $5-8$ \\
\hline \multicolumn{3}{|l|}{ Biochemical tests } \\
\hline Oxidase & $+\mathrm{ve}$ & + ve \\
\hline Catalase & + ve & + ve \\
\hline Voges-Proskauer & $+\mathrm{ve}$ & $+\mathrm{ve}$ \\
\hline Indol production & $-\mathrm{ve}$ & $-\mathrm{ve}$ \\
\hline Nitrate reduced to nitrite & $+\mathrm{ve}$ & $+\mathrm{ve}$ \\
\hline \multicolumn{3}{|l|}{ Hydrolysis of } \\
\hline Casein & $+\mathrm{ve}$ & $+\mathrm{ve}$ \\
\hline Gelatin & $+\mathrm{ve}$ & + ve \\
\hline Wool & $+\mathrm{ve}$ & + ve \\
\hline Starch & $+\mathrm{ve}$ & $+\mathrm{ve}$ \\
\hline \multicolumn{3}{|l|}{ Acid from } \\
\hline Glucose & + ve & + ve \\
\hline Arabinose & $+\mathrm{ve}$ & $+\mathrm{ve}$ \\
\hline Xylose & $+\mathrm{ve}$ & $+\mathrm{ve}$ \\
\hline Mannitol & $+\mathrm{ve}$ & $+\mathrm{ve}$ \\
\hline Gas from glucose & $-\mathrm{ve}$ & $-\mathrm{ve}$ \\
\hline \multicolumn{3}{|l|}{ Utilization of } \\
\hline Citrate & $+\mathrm{ve}$ & $+\mathrm{ve}$ \\
\hline Propionate & $-\mathrm{ve}$ & - ve \\
\hline
\end{tabular}

pattern was checked by 500 bootstrap replicates (Figures 2 and 3 ).

3.4. Media Screening for Keratinolytic Protease Production. Keratinolytic proteases are largely produced in a basal medium with keratinous substrates, and most of the organisms could utilize keratin sources such as feather and wool as the sole source of carbon and nitrogen [35, 36]. B. amyloliquefaciens MA20 and B. subtilis MA21 were tested on eight nutrient media. The selected media is medium (1) which is containing (w/v) NaCl, $0.5 \mathrm{~g} / \mathrm{L} ; \mathrm{K}_{2} \mathrm{HPO}_{4}, 0.3 \mathrm{~g} / \mathrm{L} ; \mathrm{KH}_{2} \mathrm{PO}_{4}$, $0.4 \mathrm{~g} / \mathrm{L}$; wool, $10 \mathrm{~g} / \mathrm{L}$, and the $\mathrm{pH}$ was adjusted 7.0-7.2 using $2 \mathrm{~N}$ of $\mathrm{NaOH}$ and $\mathrm{HCl}$.

Korniłłowicz-Kowalska, (1997) and Amara and Serour (2008) reported that the mass loss of the keratin substrate is the most reliable indicator of microbial keratinolytic abilities. B. amyloliquefaciens MA20 and B. subtilis MA21 have the ability to degrade wool completely after incubation for 5 days and remain it as powders in the bottom of flasks [24, 37].
3.5. Enzyme Production and Characterization. The keratinolytic protease enzyme was produced using production medium mentioned above for each of B. amyloliquefaciens MA20 and B. subtilis MA21, and the crude enzymes were characterized.

3.6. Detection of the Proteolytic Activity on Plates. The crude enzymes of B. amyloliquefaciens MA20 and B. subtilis MA21 were assayed by agar well diffusion methods on plates containing gelatin soluble in glycine/ $\mathrm{NaOH}$ buffer of $\mathrm{pH} 9$. The Coomassie blue and amido black bind to gelatin and whole plate giving the colour of dye except the hydrolysis areas which appear as transparent without dye (Figure 4).

\subsection{Characterization of Keratinolytic Protease Enzyme}

3.7.1. Influence of $\mathrm{pH}$ and Temperature. The effect of temperature and $\mathrm{pH}$ on enzymes activity and stability was determined. The optimum temperature and $\mathrm{pH}$ for protease activity of enzymes produced by B. amyloliquefaciens MA20 and B. subtilis MA21 was found to be $60^{\circ} \mathrm{C}, 9.0$, respectively.

The enzymes activity was investigated at $\mathrm{pH} 7$ and different temperatures (Figure 5). The proteolytic activities were determined at optimized temperature $60^{\circ} \mathrm{C}$ and different $\mathrm{pH}$ (Figure 6). For confirmation from the optimized reaction, the enzymes activity was assayed at $\mathrm{pH} 9$ with different temperatures (Figure 7).

Results revealed that the keratinolytic protease from $B$. amyloliquefaciens MA20 and B. subtilis MA21 is similar to those produced using bacteria, actinomycetes, and fungi and has a $\mathrm{pH}$ optimum in a neutral-to-alkaline range $[38,39]$. The optimal temperature for activity was also found in the usual range for keratinolytic protease $\left(30-80^{\circ} \mathrm{C}\right)$.

The maximum activity of protease enzyme produced by B. amyloliquefaciens MA20 was $922 \mathrm{U} / \mathrm{mL}$ at $\mathrm{pH} 9$ and $60^{\circ} \mathrm{C}$ while the maximum activity of protease enzyme produced by B. subtilis MA21 was determined as $814 \mathrm{U} / \mathrm{mL}$ at the same conditions. The alkaline $\mathrm{pH}$ of the keratinolytic protease enzyme from B. amyloliquefaciens MA20 and B. subtilis MA21 suggests a positive biotechnological potential.

The enzymes were stable at temperatures between 4 and $70^{\circ} \mathrm{C}$. The enzyme produced by $B$. amyloliquefaciens MA20 is more thermostable than enzyme produced by $B$. subtilis MA21 (Figures 8 and 9). The results of thermal stability indicated that the keratinolytic protease from B. amyloliquefaciens MA20 is more thermostable than the enzyme produced by $B$. subtilis MA21.

The thermal stability studies give the enzyme from $B$. amyloliquefaciens MA20 the advantage for using in industrial applications which are the main objective of this study.

The crude enzyme from B. amyloliquefaciens MA20 is described as stable over a broad $\mathrm{pH}$ range of $4.0-12.0$, but the best stable $\mathrm{pH}$ is 9 and 10 (Figure 10). Figure 11 indicates that the enzyme from $B$. subtilis MA21 was stable in $\mathrm{pH}$ range (5.012.0) with high stability at $\mathrm{pH}$ 9. The stability of keratinolytic proteases produced by $B$. amyloliquefaciens MA20 and $B$. subtilis MA21 has been suggested to offer great advantages for 


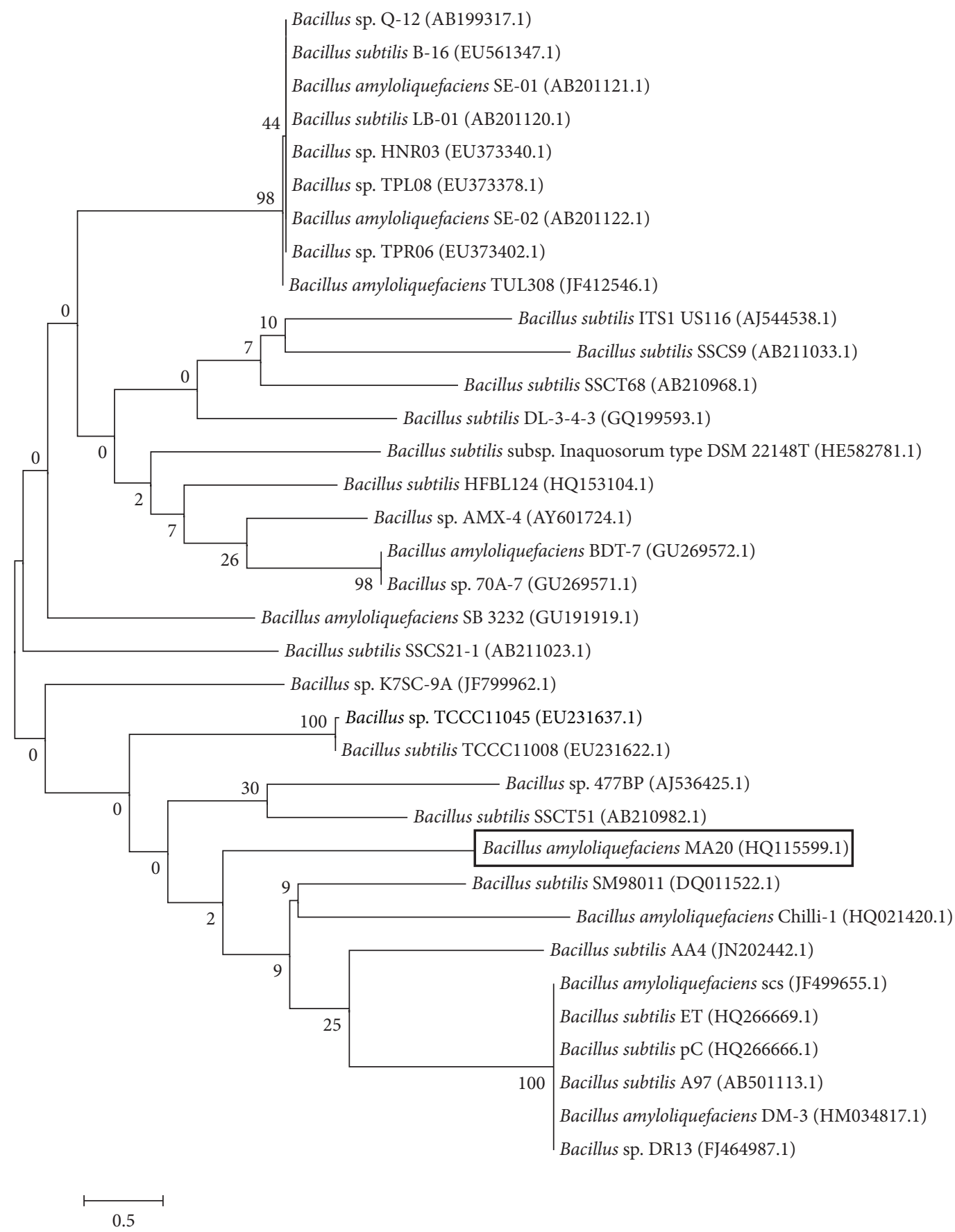

FIgURE 2: Phylogenetic position of Bacillus amyloliquefaciens MA20 within the genus Bacillus. The branching pattern was generated by neighbor-joining tree method. The Genbank accession numbers of the $16 \mathrm{~S}$ rRNA nucleotide sequences are indicated in brackets. The number of each branch indicates the bootstrap values. The bar indicates a Jukes-Cantor distance of 0.5 .

industrial purposes such as wastewater treatment and leather tanning [40].

3.8. Influence of Protease Inhibitors, Solvents, and Metal Ions on Enzymes Activity. Mostly keratinolytic proteases belong to the subtilisin family of serine proteases with cysteine proteases, which have higher activity on casein [41]. The keratinolytic proteases produced by Bacillus sp. are often serineproteases, such as the enzymes produced by $B$. licheniformis [42], B. pseudofirmus [43], and B. subtilis [44, 45]. Protease activity of enzymes prepared from $B$. amyloliquefaciens MA20 and B. subtilis MA21 was completely inhibited by serine protease inhibitor (PMSF). The result indicated the presence 


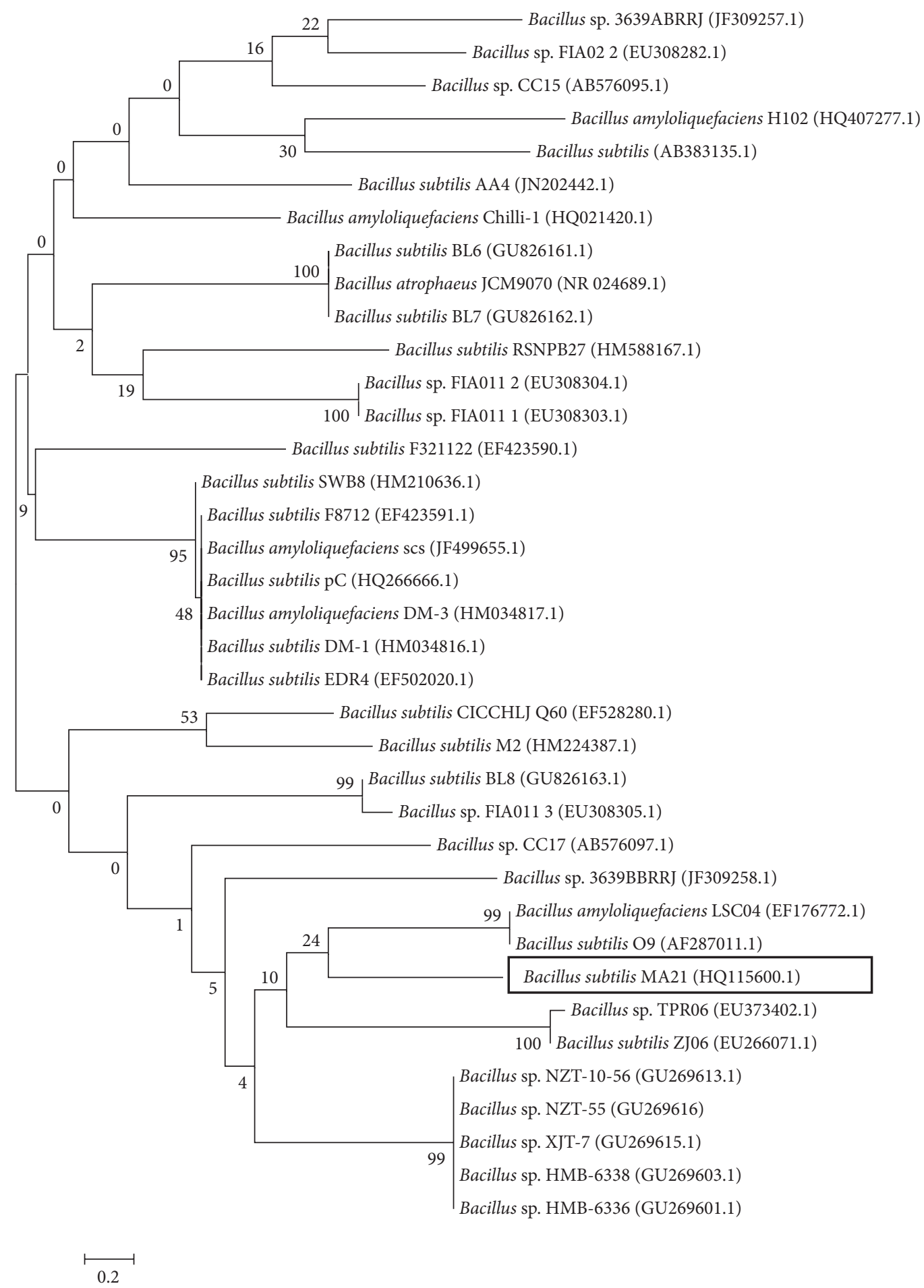

FIGURE 3: Phylogenetic position of Bacillus subtilis MA21 within the genus Bacillus. The branching pattern was generated by neighbor-joining tree method. The Genbank accession numbers of the $16 \mathrm{~S}$ rRNA nucleotide sequences are indicated in brackets. The number of each branch indicates the bootstrap values. The bar indicates a Jukes-Cantor distance of 0.2 .

of the serine group in the enzyme active site. The enzymes activity was partially inhibited by EDTA (Tables 2 and 3 ). This suggests that the keratinolytic protease from the Bacillus strain belongs to keratinolytic serine protease family.
The stability of keratinolytic proteases in presence of SDS acts as a positive advantage of enzymes feature because it indicated the possibility of using them in different industrial purposes as detergent industry, leather industry, and wool 

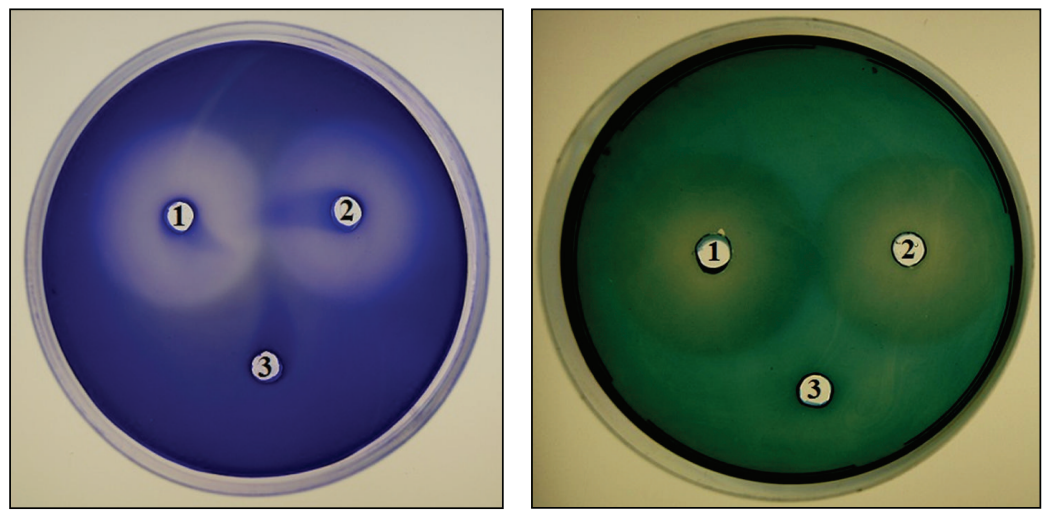

FIgURE 4: Proteolytic activity of crude enzymes produced by B. amyloliquefaciens MA20 and B. subtilis MA21 using gelatin as substrate and both of Coomassie blue and amido black stains. Blue plate stained with Coomassie blue while green plate stained with Amido black. The well (1) refers to enzymes produced by B. amyloliquefaciens MA20, (2) refers to enzymes produced by B. subtilis MA21, and (3) is inactive enzyme.

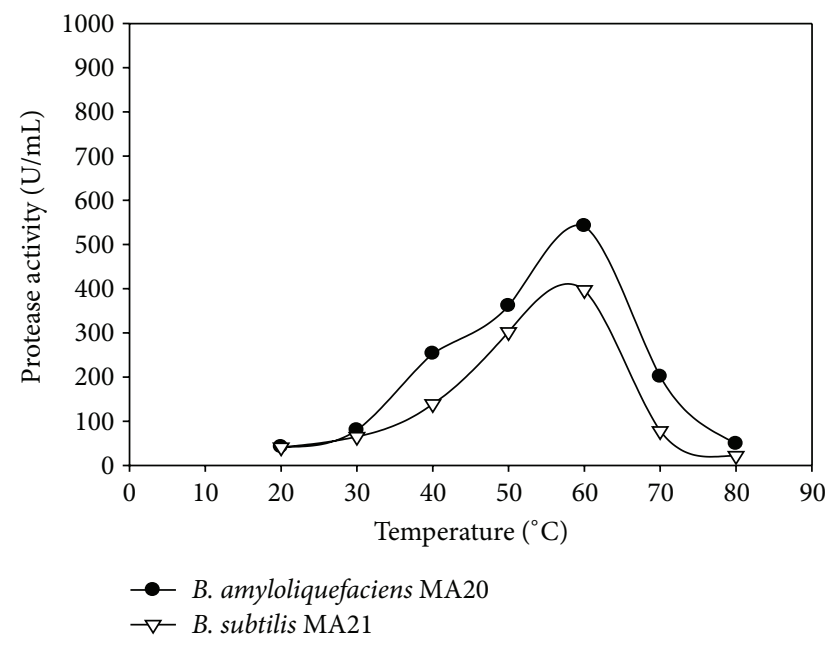

FIGURE 5: Effect of temperatures at $\mathrm{pH} 7$ on protease activity of crude enzymes produced by B. amyloliquefaciens MA20 and B. subtilis MA21.

improvement. The stability toward SDS is important because a few authors reported that SDS-stable enzymes are also not generally available except for a few strains such as Bacillus clausii I-52 [46] and Bacillus sp. RGR-14 [47]. The effects of various solvents and metal ions on enzyme activity were examined in order to find which ions are stimulators and which are inhibitors of the catalytic process.

The metal ions were used with two final concentrations $(5.0 \mathrm{mM}$ and $10 \mathrm{mM})$ while the used solvents with final concentrations ( $1 \%$ and $0.5 \%$ ). The effects of metal ions and solvents on enzyme activities are summarized in Tables 2 and 3.

3.9. First-Dimension Protein Electrophoresis. The production of extracellular keratinolytic proteases by B. amyloliquefaciens MA20 and B. subtilis MA21 was evaluated by SDS-PAGE and zymogram analysis. Giongo et al. found multiple bands after zymogram of keratinolytic protease produced by three

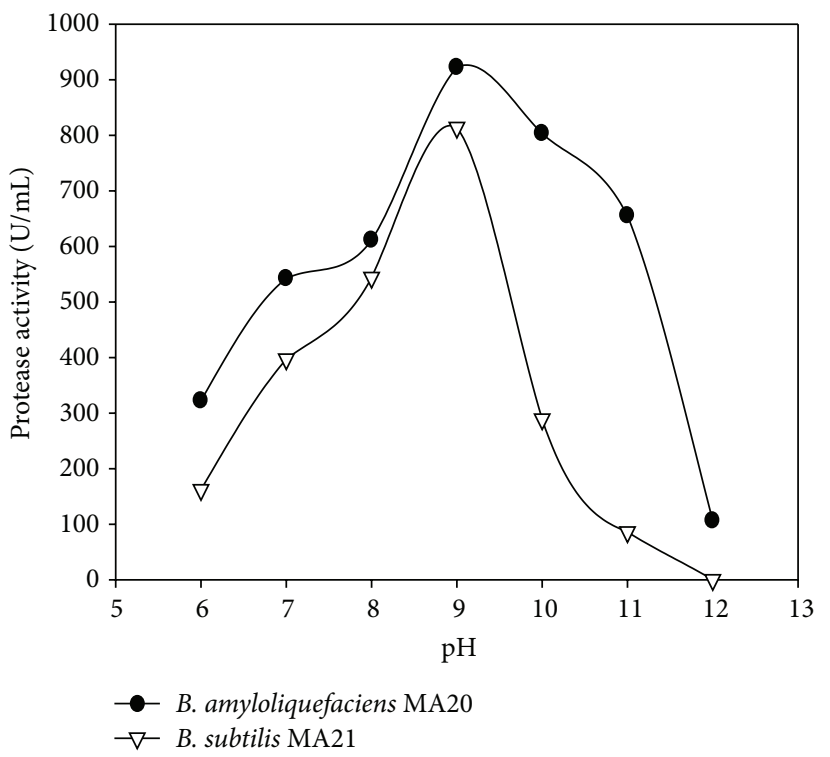

FIGURE 6: Effect of $\mathrm{pH}$ at $60^{\circ} \mathrm{C}$ on protease activity of crude enzymes produced by B. amyloliquefaciens MA20 and B. subtilis MA21.

strains of Bacillus sp. P6, P7, and P11 using feather degrading medium [25]. Growth of the two strains in presence $10 \mathrm{~g} / \mathrm{L}$ of wool resulted in the production of multiple proteases, as observed by a zymogram on gelatin (Figures 12 and 13). Multiple clear zones were observed and detected using (PAGE Ruler Prestained Protein Ladder) which indicated that the proteolytic activity was not due to a single protein. The native-PAGE zymogram of enzymes from the 2 strains was performed and compared with protein ladder (Figures 14 and 15). The zymogram using native page was carried out for detecting the bands of protein where the purification performs using native protein. Multiple bands could be detected on native-PAGE zymogrm.

3.10. Two-Dimension Protein Electrophoresis. The twodimensional polyacrylamide gel electrophoresis (2D-PAGE) 
TABLE 2: Effect of protease inhibitors, metal ions, and solvents on proteolytic activity of B. amyloliquefaciens MA20.

\begin{tabular}{|c|c|c|c|c|}
\hline Substance & Final concentration & Relative activity (\%) & Final concentration & Relative activity (\%) \\
\hline Control & 0 & 100 & 0 & 100 \\
\hline$\beta$-mercaptoethanol & $5 \mathrm{mM}$ & 18 & $1 \mathrm{mM}$ & 98 \\
\hline PMSF & $5 \mathrm{mM}$ & 0 & $1 \mathrm{mM}$ & 0 \\
\hline EDTA & $5 \mathrm{mM}$ & 35 & $1 \mathrm{mM}$ & 97 \\
\hline SDS & $0.5 \%$ & 54 & $0.1 \%$ & 122 \\
\hline $\mathrm{ZnCl}_{2}$ & $10 \mathrm{mM}$ & 153 & $5 \mathrm{mM}$ & 156 \\
\hline $\mathrm{MgCl}_{2}$ & $10 \mathrm{mM}$ & 119 & $5 \mathrm{mM}$ & 95 \\
\hline $\mathrm{CuSO}_{4}$ & $10 \mathrm{mM}$ & 266 & $5 \mathrm{mM}$ & 204 \\
\hline Urea & $10 \mathrm{mM}$ & 114 & $5 \mathrm{mM}$ & 139 \\
\hline $\mathrm{HgCl}_{2}$ & $10 \mathrm{mM}$ & 100.4 & $5 \mathrm{mM}$ & 107 \\
\hline $\mathrm{CaCl}_{2}$ & $10 \mathrm{mM}$ & 104 & $5 \mathrm{mM}$ & 107 \\
\hline $\mathrm{BaCl}_{2}$ & $10 \mathrm{mM}$ & 115 & $5 \mathrm{mM}$ & 116 \\
\hline Guanidin $\mathrm{HCl}$ & $10 \mathrm{mM}$ & 103 & $5 \mathrm{mM}$ & 132 \\
\hline $\mathrm{MnCl}_{2}$ & $10 \mathrm{mM}$ & 71 & $5 \mathrm{mM}$ & 162 \\
\hline Methanol & $1 \%$ & 90 & $0.5 \%$ & 100 \\
\hline Ethanol & $1 \%$ & 103 & $0.5 \%$ & 100 \\
\hline DMSO & $1 \%$ & 90 & $0.5 \%$ & 103 \\
\hline Isopropanol & $1 \%$ & 98 & $0.5 \%$ & 108 \\
\hline Tween 20 & $1 \%$ & 86 & $0.5 \%$ & 94 \\
\hline Triton X100 & $1 \%$ & 61 & $0.5 \%$ & 65 \\
\hline
\end{tabular}

TABLE 3: Effect of protease inhibitors, metal ions, and solvents on proteolytic activity of B. subtilis MA21.

\begin{tabular}{|c|c|c|c|c|}
\hline Substance & Final concentration & Relative activity (\%) & Final concentration & Relative activity (\%) \\
\hline Control & 0 & 100 & 0 & 100 \\
\hline$\beta$-mercaptoethanol & $5 \mathrm{mM}$ & 48 & $1 \mathrm{mM}$ & 70 \\
\hline PMSF & $5 \mathrm{mM}$ & 0 & $1 \mathrm{mM}$ & 0 \\
\hline EDTA & $5 \mathrm{mM}$ & 13 & $1 \mathrm{mM}$ & 96 \\
\hline SDS & $0.5 \%$ & 25 & $0.1 \%$ & 99 \\
\hline $\mathrm{ZnCl}_{2}$ & $10 \mathrm{mM}$ & 92 & $5 \mathrm{mM}$ & 93 \\
\hline $\mathrm{MgCl}_{2}$ & $10 \mathrm{mM}$ & 22 & $5 \mathrm{mM}$ & 98 \\
\hline $\mathrm{CuSO}_{4}$ & $10 \mathrm{mM}$ & 23 & $5 \mathrm{mM}$ & 73 \\
\hline Urea & $10 \mathrm{mM}$ & 24 & $5 \mathrm{mM}$ & 52 \\
\hline $\mathrm{HgCl}_{2}$ & $10 \mathrm{mM}$ & 27 & $5 \mathrm{mM}$ & 37 \\
\hline $\mathrm{CaCl}_{2}$ & $10 \mathrm{mM}$ & 65 & $5 \mathrm{mM}$ & 142 \\
\hline $\mathrm{BaCl}_{2}$ & $10 \mathrm{mM}$ & 29 & $5 \mathrm{mM}$ & 69 \\
\hline Guanidin $\mathrm{HCl}$ & $10 \mathrm{mM}$ & 42 & $5 \mathrm{mM}$ & 49 \\
\hline $\mathrm{MnCl}_{2}$ & $10 \mathrm{mM}$ & 64 & $5 \mathrm{mM}$ & 67 \\
\hline Methanol & $1 \%$ & 92 & $0.5 \%$ & 99 \\
\hline Ethanol & $1 \%$ & 92 & $0.5 \%$ & 97 \\
\hline DMSO & $1 \%$ & 78 & $0.5 \%$ & 96 \\
\hline Isopropanol & $1 \%$ & 98 & $0.5 \%$ & 101 \\
\hline Tween 20 & $1 \%$ & 78 & $0.5 \%$ & 86 \\
\hline Triton X100 & $1 \%$ & 57 & $0.5 \%$ & 133 \\
\hline
\end{tabular}

TABLE 4: Two-dimension protein gel electrophoresis report of crude enzymes produced by B. amyloliquefaciens MA20 and B. subtilis MA21.

\begin{tabular}{lccccccc}
\hline Gels & Spots & Minimum gray & Maximum gray & Columns & Rows & Pixel width & Pixel height \\
\hline B. amyloliquefaciens MA20 & 237 & 23 & 209 & 2512 & 1510 & 353 & 353 \\
B. subtilis MA21 & 291 & 0 & 255 & 2336 & 1452 & 353 & 353 \\
\hline
\end{tabular}




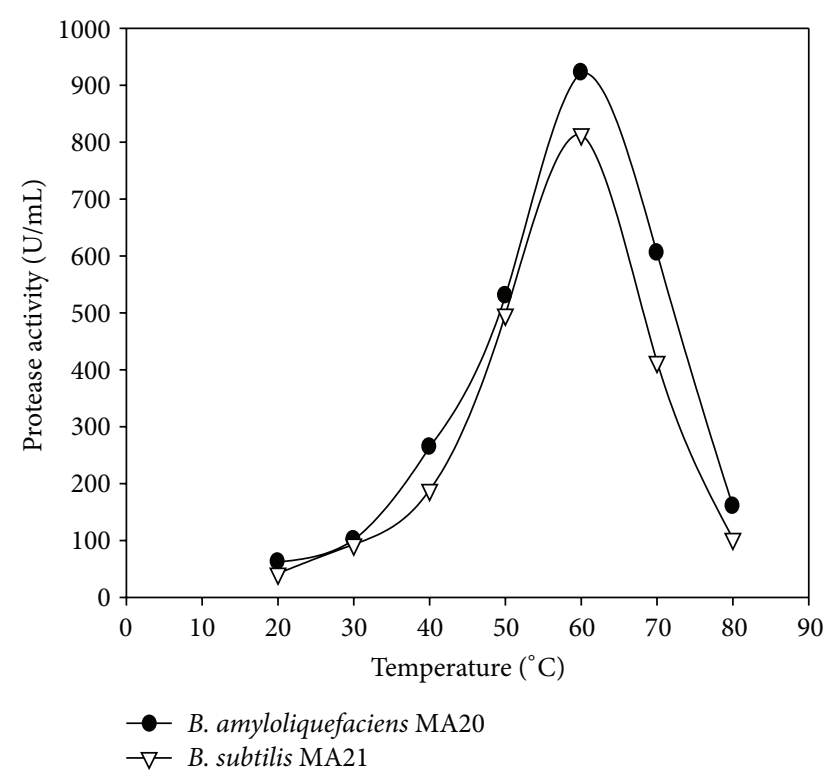

FIGURE 7: Effect of temperatures at $\mathrm{pH} 9$ on protease activity of crude enzymes produced by B. amyloliquefaciens MA20 and B. subtilis MA21.

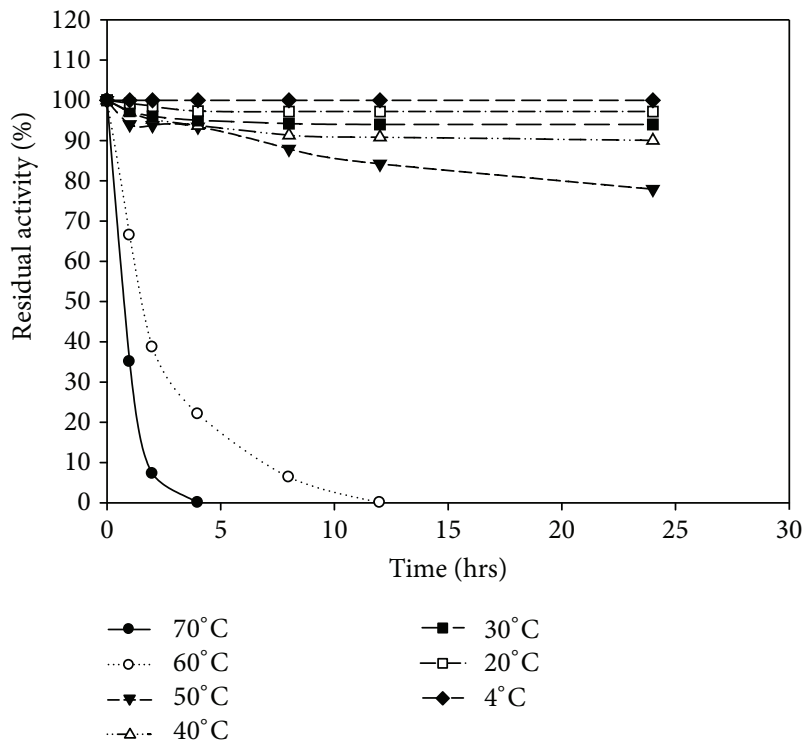

FIGURE 8: Thermal stability of crude enzyme produced by $B$. amyloliquefaciens MA20.

is an advanced technique that depends on protein separation firstly according to the $\mathrm{pH}$ and secondly based on the molecular weight. This technique was carried out to differentiate between the crude keratinolytic proteases obtained from B. amyloliquefaciens MA20 and B. subtilis MA21. After the separation based on the $\mathrm{pH}$, the strips were applied on gel for separating according to molecular weight. The gels were stained with Coomassie blue for detecting the protein spots.

In order to classify the keratinolytic protease enzyme, a systemic comparison of 2D maps of proteases was conducted

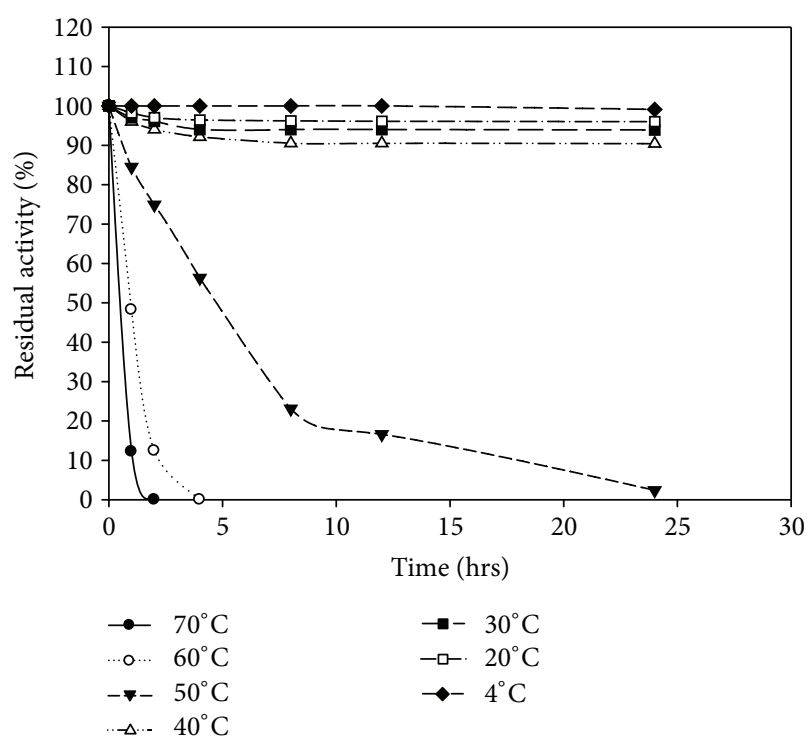

FIGURE 9: Thermal stability of crude enzyme produced by B. subtilis MA21.

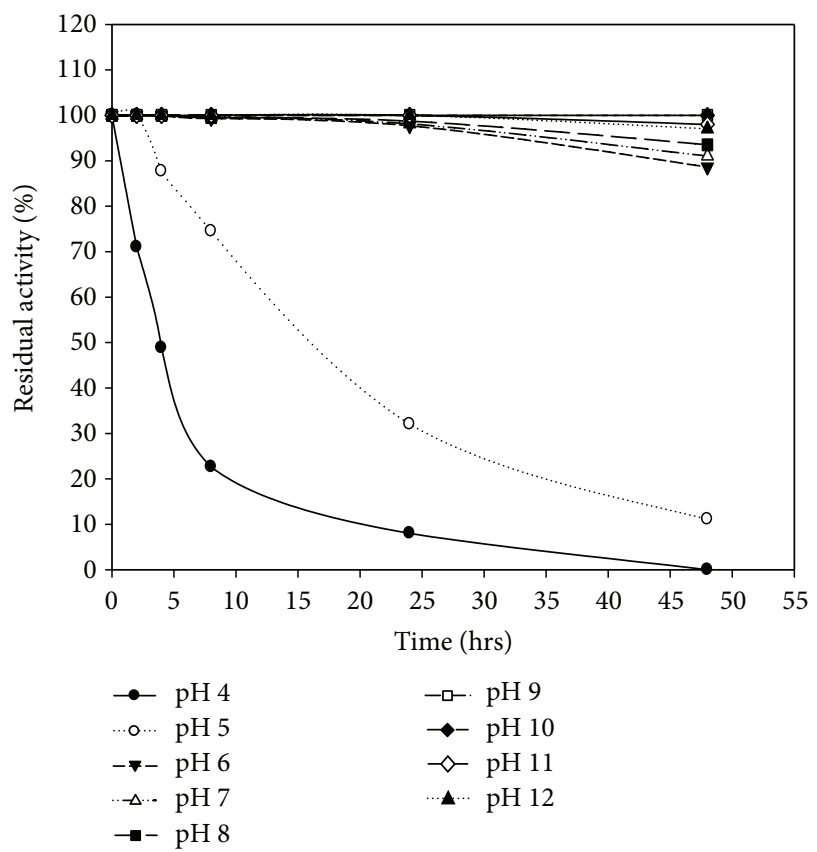

FIGURE 10: pH stability of crude enzyme produced by B. amyloliquefaciens MA20.

with image master 2D Platinum 6 software. The two gels were photographed by high quality scanner image (Figure 16).

The results were analyzed using image master 2D Platinum 6 software. The spots were detected before matching between the two gels and the report was obtained (Table 4). Every spot refers to the presence of one protein. The gel which was loaded with keratinolytic protease from $B$. amyloliquefaciens MA20 had 237 spots while the gel applied with B. subtilis MA21 had 291 spots. 


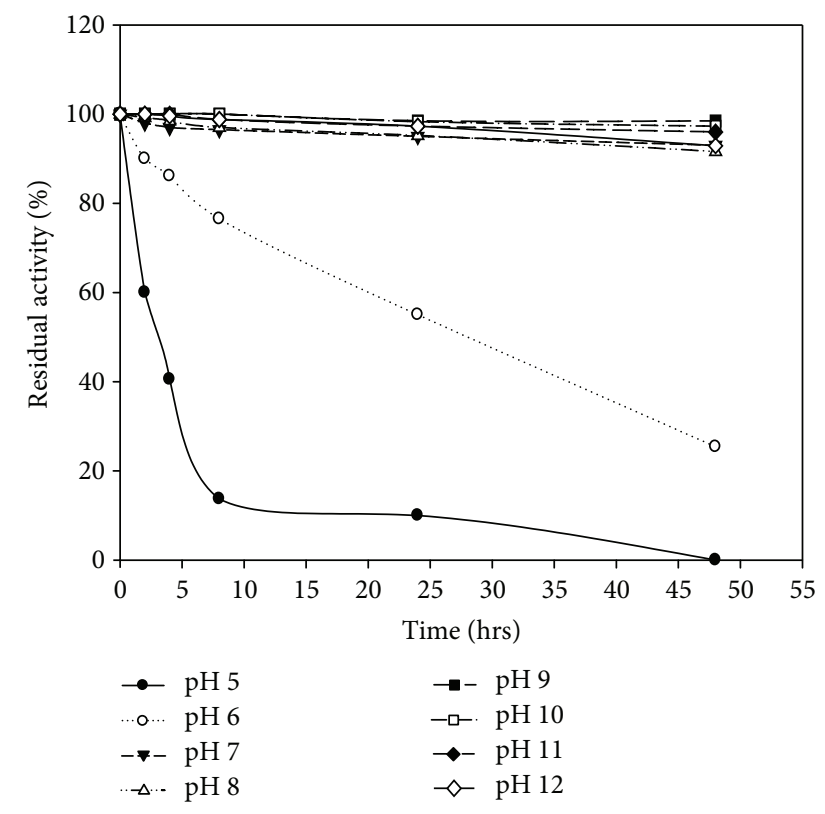

FIGURE 11: $\mathrm{pH}$ stability of crude enzyme produced by $B$. subtilis MA21.

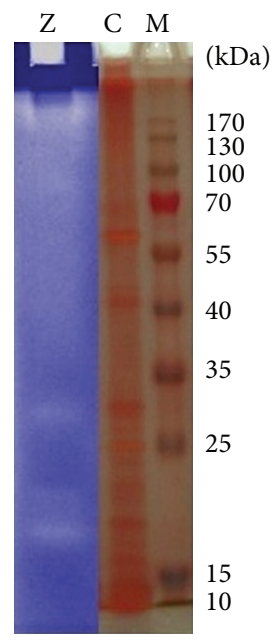

FIGURE 12: SDS-PAGE and zymogram analysis of keratinolytic protease enzyme from B. amyloliquefaciens MA20. The lane (M) is prestained protein ladder, lane $(C)$ is protein pattern of crude enzyme, and lane $(Z)$ is zymogram of enzyme.

The 2 gels were matched and consider gel resulted from crude enzymes of $B$. amyloliquefaciens MA20 as reference and the final report that summarizes the difference between 2 gels was obtained (Table 5). The 2 gels were matched and the percent of matching between them was $13.25 \%$.

\section{Conclusion}

This paper described in details different methods that lead to the production of keratinolytic protease from two Bacillus sp. strains. Different methods and assays ranging from simple to advanced were carried out to prove that the enzymes have

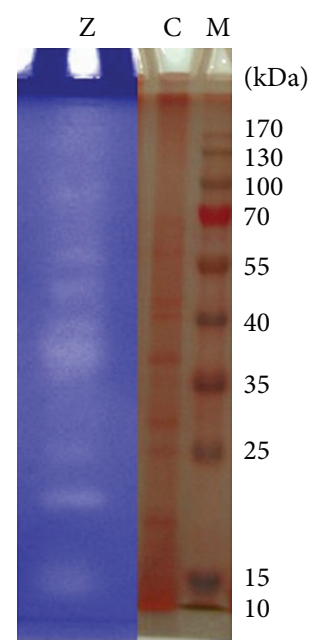

FIGURE 13: SDS-PAGE and zymogram analysis of keratinolytic protease enzyme from $B$. subtilis MA21. The lane (M) is prestained protein ladder, lane $(\mathrm{C})$ is protein pattern of crude enzyme, and lane (Z) is zymogram of enzyme.

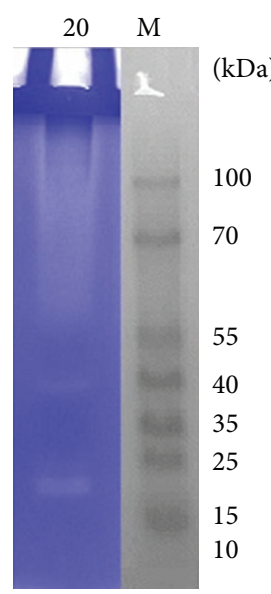

FIGURE 14: Native-PAGE zymogram analysis of keratinolytic protease enzyme from B. amyloliquefaciens MA20. The lane (M) is prestained protein ladder, and lane (20) is zymogram of enzyme.

TABLE 5: Match statistics report of crude enzymes produced by $B$. amyloliquefaciens MA20 and B. subtilis MA21 after two-dimension protein gel electrophoresis.

\begin{tabular}{lccc}
\hline Gel name & Gel name & $\begin{array}{c}\text { Number of } \\
\text { matches }\end{array}$ & $\begin{array}{c}\text { Percent } \\
\text { matches }\end{array}$ \\
\hline $\begin{array}{l}\text { B. amyloliquefaciens } \\
\text { MA20 (reference) }\end{array}$ & B. subtilis MA21 & 35 & 13.2576 \\
\hline
\end{tabular}

the ability to degrade wool. The two used strains have been selected based on that they belong to Bacillus sp. and show the best keratinolytic activities. The study included molecular and bioinformatic tools to identify the two Bacillus sp. strains. 16S rRNA, phylogenetic tree, Blast search for nucleotide similarity, scanning electron microscope, SDS-PAGE, and 2D-PAGE have been used to differentiate the both strains 


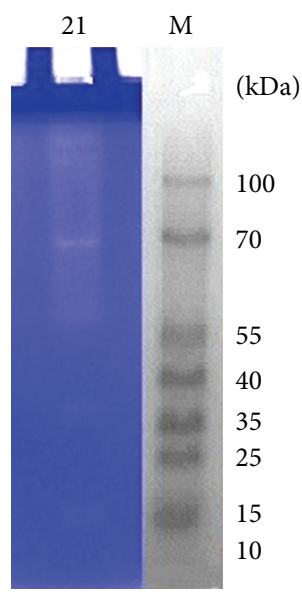

FIGURE 15: Native-PAGE zymogram analysis of keratinolytic protease enzyme from $B$. subtilis MA21. The lane (M) is prestained protein ladder, and lane (21) is zymogram of enzyme.

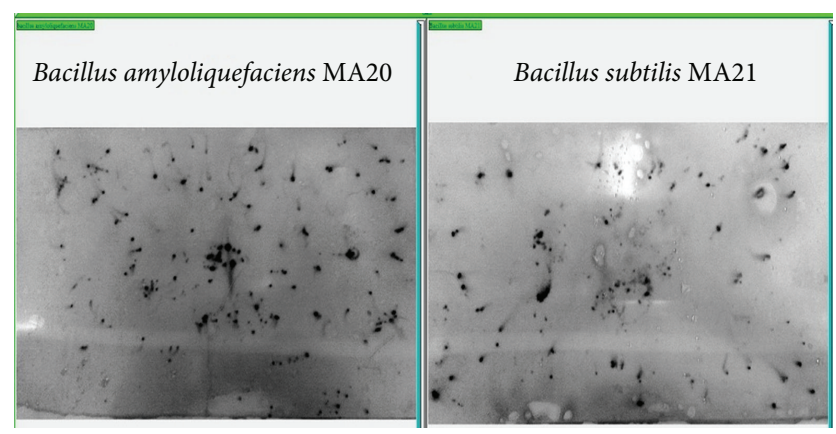

FIGURE 16: Two-dimension gel of enzymes from B. amyloliquefaciens MA20 and B. subtilis MA21.

and their produced enzymes. The study succeeded in characterization of Bacillus sp. strains which were named Bacillus amyloliquefaciens MA20 and Bacillus subtilis MA21. The enzyme activities either on agar diffusion plates or through the enzyme activity bioassays under different experimental conditions proved that the both strains are able to produce different keratinolytic protease enzymes. B. amyloliquefaciens MA20 and B. subtilis MA21 could be used in large-scale production of keratinolytic protease enzymes where these enzymes were stable at temperature range between 4 and $70^{\circ} \mathrm{C}$, and over a wide range of $\mathrm{pH}$ values (4-12), as well as, stable against organic solvents and detergents. The characters of keratinolytic enzymes produced by $B$. amyloliquefaciens MA20 and B. subtilis MA21 could play an important role especially in industrial applications; therefore this research acts as preliminary studies for applying the keratinolytic proteases in wool quality improvement.

\section{References}

[1] T. Korniłłowicz-Kowalska and J. Bohacz, "Biodegradation of keratin waste: theory and practical aspects," Waste Management, vol. 31, pp. 1689-1701, 2011.
[2] R. D. B. Fraser and D. A. D. Parry, "Macrofibril assembly in trichocyte (hard $\alpha$-) keratins," Journal of Structural Biology, vol. 142, no. 2, pp. 319-325, 2003.

[3] L. N. Jones, "Hair structure anatomy and comparative anatomy," Clinics in Dermatology, vol. 19, no. 2, pp. 95-103, 2001.

[4] P. Pillai and G. Archana, "Hide depilation and feather disintegration studies with keratinolytic serine protease from a novel Bacillus subtilis isolate," Applied Microbiology and Biotechnology, vol. 78, no. 4, pp. 643-650, 2008.

[5] V. Filipello Marchisio, "Karatinophilic fungi: their role in nature and degradation of keratinic substrates," in Biology of Dermatophytes and Other Keratinophilic Fungi, R. K. S. Kushawaha and J. Guarro, Eds., vol. 17, pp. 86-92, Revista Iberoamericana de Micología, 2000.

[6] R. Gupta and P. Ramnani, "Microbial keratinases and their prospective applications:an overview," Applied Microbiology and Biotechnology, vol. 70, pp. 21-33, 2006.

[7] S. Sangali and A. Brandelli, "Feather keratin hydrolysis by a Vibrio sp. strain kr2," Journal of Applied Microbiology, vol. 89, no. 5, pp. 735-743, 2000.

[8] C. H. De Toni, M. F. Richter, J. R. Chagas, J. A. P. Henriques, and C. Termignoni, "Purification and characterization of an alkaline serine endopeptidase from a feather-degrading Xanthomonas maltophilia strain," Canadian Journal of Microbiology, vol. 48, no. 4, pp. 342-348, 2002.

[9] F. S. Lucas, O. Broennimann, I. Febbraro, and P. Heeb, "High diversity among feather-degrading bacteria from a dry meadow soil," Microbial Ecology, vol. 45, no. 3, pp. 282-290, 2003.

[10] S. Yamamura, Y. Morita, Q. Hasan et al., "Characterization of a new keratin-degrading bacterium isolated from deer fur," Journal of Bioscience and Bioengineering, vol. 93, no. 6, pp. 595600, 2002.

[11] E. H. Brutt and J. M. Ichida, "Keratinase produced by Bacillus licheniformis," US Patent 5,877,000, 1999.

[12] A. Gousterova, D. Braikova, I. Goshev et al., "Degradation of keratin and collagen containinq wastes by newly isolated thermoactinomycetes or by alkaline hydrolysis," Letters in Applied Microbiology, vol. 40, no. 5, pp. 335-340, 2005.

[13] K. L. Evans, J. Crowder, and E. S. Miller, "Subtilisins of Bacillus spp. hydrolyze keratin and allow growth on feathers," Canadian Journal of Microbiology, vol. 46, no. 11, pp. 1004-1011, 2000.

[14] I. N. S. Dozie, C. N. Okeke, and N. C. Unaeze, "A thermostable, alkaline-active, keratinolytic proteinase from Chrysosporium keratinophilum," World Journal of Microbiology and Biotechnology, vol. 10, no. 5, pp. 563-567, 1994.

[15] A. Riffel, F. Lucas, P. Heeb, and A. Brandelli, "Characterization of a new keratinolytic bacterium that completely degrades native feather keratin," Archives of Microbiology, vol. 179, no. 4, pp. 258-265, 2003.

[16] B. Zhang, D. Jiang, W. Zhou, H. Hao, and T. Niu, "Isolation and characterization of a new Bacillus sp. 50-3 with highly alkaline keratinase activity from Calotes versicolor faeces," World Journal of Microbiology and Biotechnology, vol. 25, no. 4, pp. 583-590, 2009.

[17] J. G. Holt, N. R. Krieg, P. H. A. Sneath, J. T. Staley, and S. T. Williams, Bergey's Manual of Determinative Bacteriology, Williams \& Wilkins, Baltimore, Md, USA, 9th edition, 1994.

[18] J. Sambrook, E. F. Fritsch, and T. Maniatis, Molecular Cloning: A Laboratory Manual, Cold Spring Harbor Laboratory, Cold Spring Harbor, New York, NY, USA, 2nd edition, 1989. 
[19] F. Sanger, S. Nicklen, and A. R. Coulson, "DNA sequencing with chain-terminating inhibitors," Proceedings of the National Academy of Sciences of the United States of America, vol. 74, no. 12, pp. 5463-5467, 1977.

[20] K. Tamura, D. Peterson, N. Peterson, G. Stecher, M. Nei, and S. Kumar, "MEGA5: molecular evolutionary genetics analysis using maximum likelihood, evolutionary distance, and maximum parsimony methods," Molecular Biology and Evolution, vol. 28, pp. 2731-2739, 2011.

[21] A. A. Amara, R. S. Slem, and S. A. M. Shabeb, "The possibility to use crude proteases and lipases as biodetergent," Global Journal of Biotechnology \& Biochemistry, vol. 4, no. 2, pp. 104-114, 2009.

[22] W. Mao, R. Pan, and D. Freedman, "High production of alkaline protease by Bacillus licheniformis in a fed-batch fermentation using a synthetic medium," Journal of Industrial Microbiology, vol. 11, no. 1, pp. 1-6, 1992.

[23] A. B. Vermelho, M. N. L. Meirelles, A. Lopes, S. D. G. Petinate, A. A. Chaia, and M. H. Branquinha, "Detection of extracellular proteases from microorganisms on agar plates," Memorias do Instituto Oswaldo Cruz, vol. 91, no. 6, pp. 755-760, 1996.

[24] A. A. Amara and A. E. Serour, "Wool quality improvement using thermophilic crude proteolytic microbial enzymes," AmericanEurasian Journal of Agricultural \& Environmental Sciences, vol. 3, no. 4, pp. 554-560, 2008.

[25] J. L. Giongo, F. S. Lucas, F. Casarin, P. Heeb, and A. Brandelli, "Keratinolytic proteases of Bacillus species isolated from the Amazon basin showing remarkable de-hairing activity," World Journal of Microbiology and Biotechnology, vol. 23, no. 3, pp. 375-382, 2007.

[26] U. K. Laemmli, "Cleavage of structural proteins during the assembly of the head of bacteriophage T4," Nature, vol. 227, no. 5259, pp. 680-685, 1970.

[27] H. Blum, H. Beier, and J. H. Gross, "Improved silver staining of plant proteins, RNA and DNA in polyacrylamide gels," Electrophoresis, vol. 8, pp. 93-99, 1987.

[28] R. Gupta, Q. Beg, and P. Lorenz, "Bacterial alkaline proteases: molecular approaches and industrial applications," Applied Microbiology and Biotechnology, vol. 59, no. 1, pp. 15-32, 2002.

[29] J. Cortez, P. L. R. Bonner, and M. Griffin, “Transglutaminase treatment of wool fabrics leads to resistance to detergent damage," Journal of Biotechnology, vol. 117, no. 1, pp. 379-386, 2005.

[30] J. M. Kim, W. J. Lim, and H. J. Suh, "Feather-degrading Bacillus species from poultry waste," Process Biochemistry, vol. 37, no. 3, pp. 287-291, 2001.

[31] M. Rozs, L. Manczinger, C. Vágvölgyi, and F. Kevei, "Secretion of a trypsin-like thiol protease by a new keratinolytic strain of Bacillus licheniformis," FEMS Microbiology Letters, vol. 205, no. 2, pp. 221-224, 2001.

[32] M. S. Roberts, L. K. Nakamura, and F. M. Cohan, "Bacillus mojavensis sp. nov., distinguishable from Bacillus subtilis by sexual isolation, divergence in DNA sequence, and differences in fatty acid composition," International Journal of Systematic Bacteriology, vol. 44, no. 2, pp. 256-264, 1994.

[33] M. S. Roberts, L. K. Nakamura, and F. M. Cohan, "Bacillus vallismortis sp. nov., a close relative of Bacillus subtilis, isolated from soil in Death Valley, California," International Journal of Systematic Bacteriology, vol. 46, no. 2, pp. 470-475, 1996.

[34] L. T. Wang, F. L. Lee, C. J. Tai, and H. Kasai, "Comparison of gyrB gene sequences, $16 \mathrm{~S}$ rRNA gene sequences and DNADNA hybridization in the Bacillus subtilis group," International
Journal of Systematic and Evolutionary Microbiology, vol. 57, no. 8, pp. 1846-1850, 2007.

[35] I. Szabó, A. Benedek, I. Mihály Szabó, and G. Barabás, “Feather degradation with a thermotolerant Streptomyces graminofaciens strain," World Journal of Microbiology and Biotechnology, vol. 16, no. 3, pp. 253-255, 2000.

[36] A. Gushterova, E. Vasileva-Tonkova, E. Dimova, P. Nedkov, and T. Haertlé, "Keratinase production by newly isolated Antarctic actinomycete strains," World Journal of Microbiology and Biotechnology, vol. 21, no. 6-7, pp. 831-834, 2005.

[37] T. Korniłłowicz-Kowalska, "Studies on the decomposition of keratin wastes by saprotrophic microfungi. P.I. Criteria for evaluating keratinolytic activity," Acta Mycologica, vol. 32, pp. 51-79, 1997.

[38] B. Bockle, B. Galunsky, and R. Muller, "Characterization of a keratinolytic serine proteinase from Streptomyces pactum DSM 40530," Applied and Environmental Microbiology, vol. 61, no. 10, pp. 3705-3710, 1995.

[39] P. Bressollier, F. Letourneau, M. Urdaci, and B. Verneuil, "Purification and characterization of a keratinolytic serine proteinase from Streptomyces albidoflavus," Applied and Environmental Microbiology, vol. 65, no. 6, pp. 2570-2576, 1999.

[40] H. Takami, Y. Nogi, and K. Horikoshi, "Reidentification of the keratinase-producing facultatively alkaliphilic Bacillus sp. AH101 as Bacillus halodurans," Extremophiles, vol. 3, no. 4, pp. 293296, 1999.

[41] S. Sangali and A. Brandelli, "Isolation and characterization of a novel feather-degrading bacterial strain," Applied Biochemistry and Biotechnology A, vol. 87, no. 1, pp. 17-24, 2000.

[42] X. Lin, D. W. Kelemen, E. S. Miller, and J. C. H. Shih, "Nucleotide sequence and expression of kerA, the gene encoding a keratinolytic protease of Bacillus licheniformis PWD-1," Applied and Environmental Microbiology, vol. 61, no. 4, pp. 1469-1474, 1995.

[43] M. Kojima, M. Kanai, M. Tominaga, S. Kitazume, A. Inoue, and K. Horikoshi, "Isolation and characterization of a featherdegrading enzyme from Bacillus pseudofirmus FA30-01," Extremophiles, vol. 10, no. 3, pp. 229-235, 2006.

[44] T. I. Zaghloul, "Cloned Bacillus subtilis alkaline protease (aprA) gene showing high level of keratinolytic activity," Applied Biochemistry and Biotechnology A, vol. 70-72, pp. 199-205, 1998.

[45] H. J. Suh and H. K. Lee, "Characterization of a keratinolytic serine protease from bacillus subtilis KS-1," Protein Journal, vol. 20, no. 2, pp. 165-169, 2001.

[46] H. S. Joo, C. G. Kumar, G. C. Park, S. R. Paik, and C. S. Chang, "Oxidant and SDS-stable alkaline protease from Bacillus clausii I-52: production and some properties," Journal of Applied Microbiology, vol. 95, no. 2, pp. 267-272, 2003.

[47] R. Oberoi, Q. K. Beg, S. Puri, R. K. Saxena, and R. Gupta, "Characterization and wash performance analysis of an SDSstable alkaline protease from a Bacillus sp.," World Journal of Microbiology and Biotechnology, vol. 17, no. 5, pp. 493-497, 2001. 

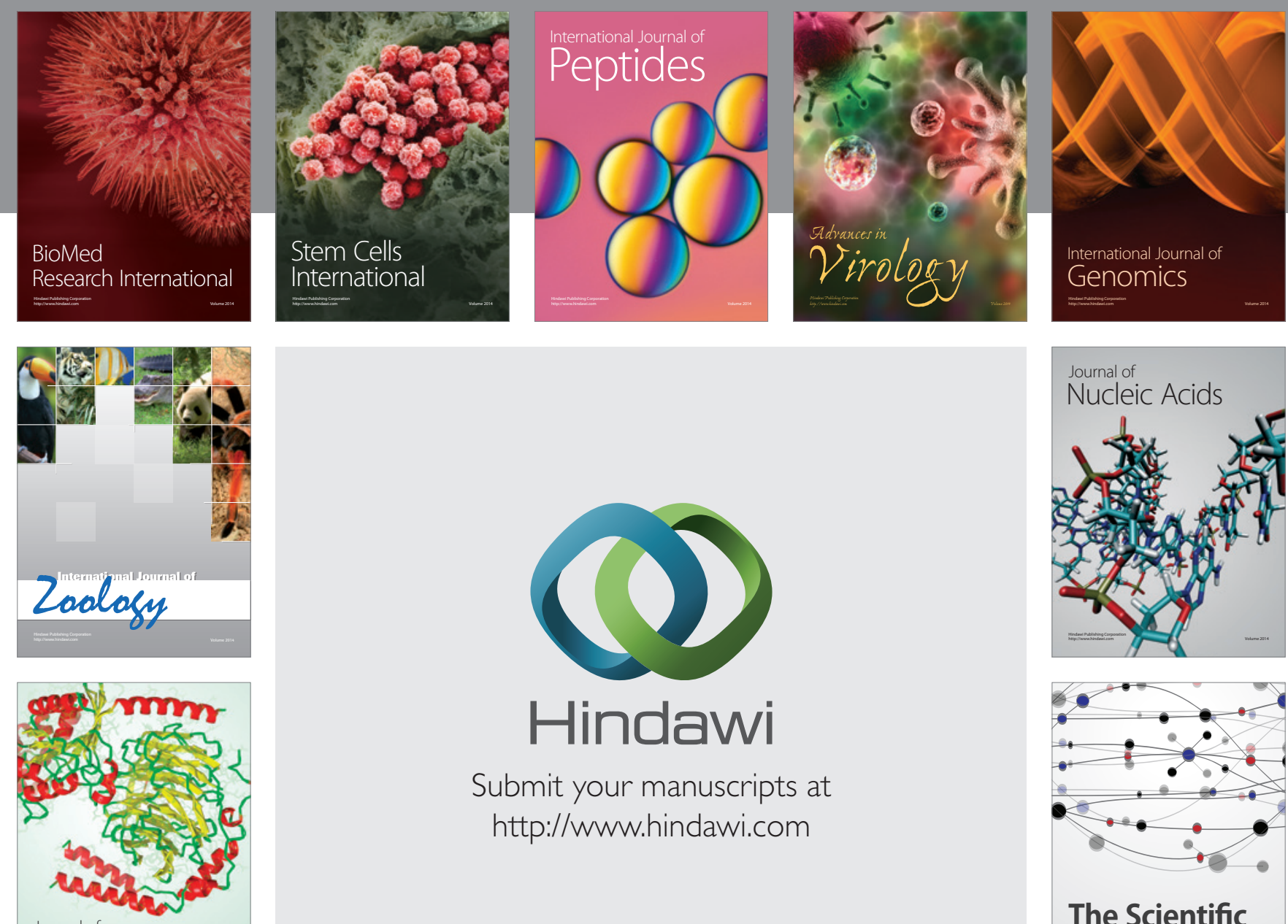

Submit your manuscripts at

http://www.hindawi.com

Journal of
Signal Transduction
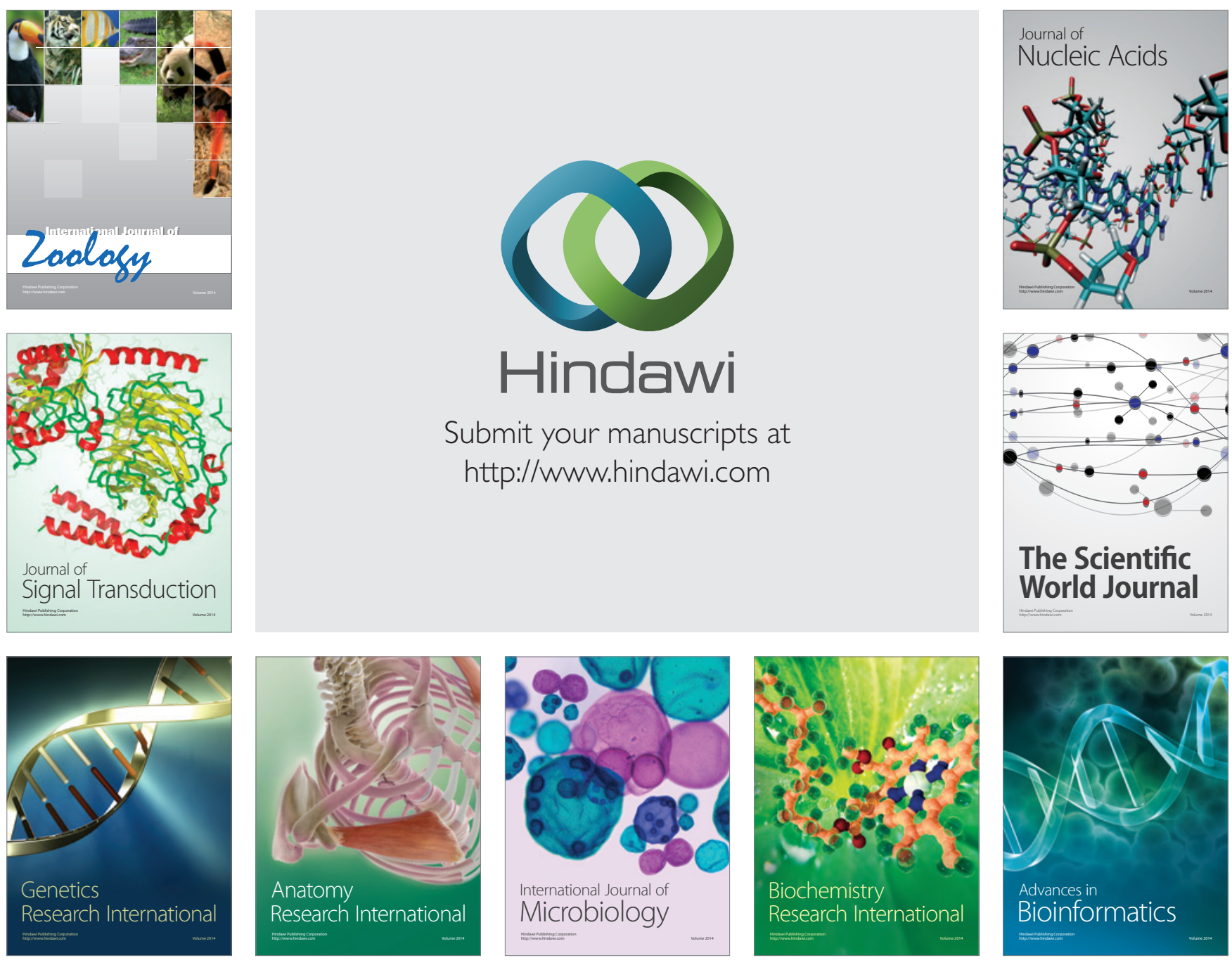

The Scientific World Journal
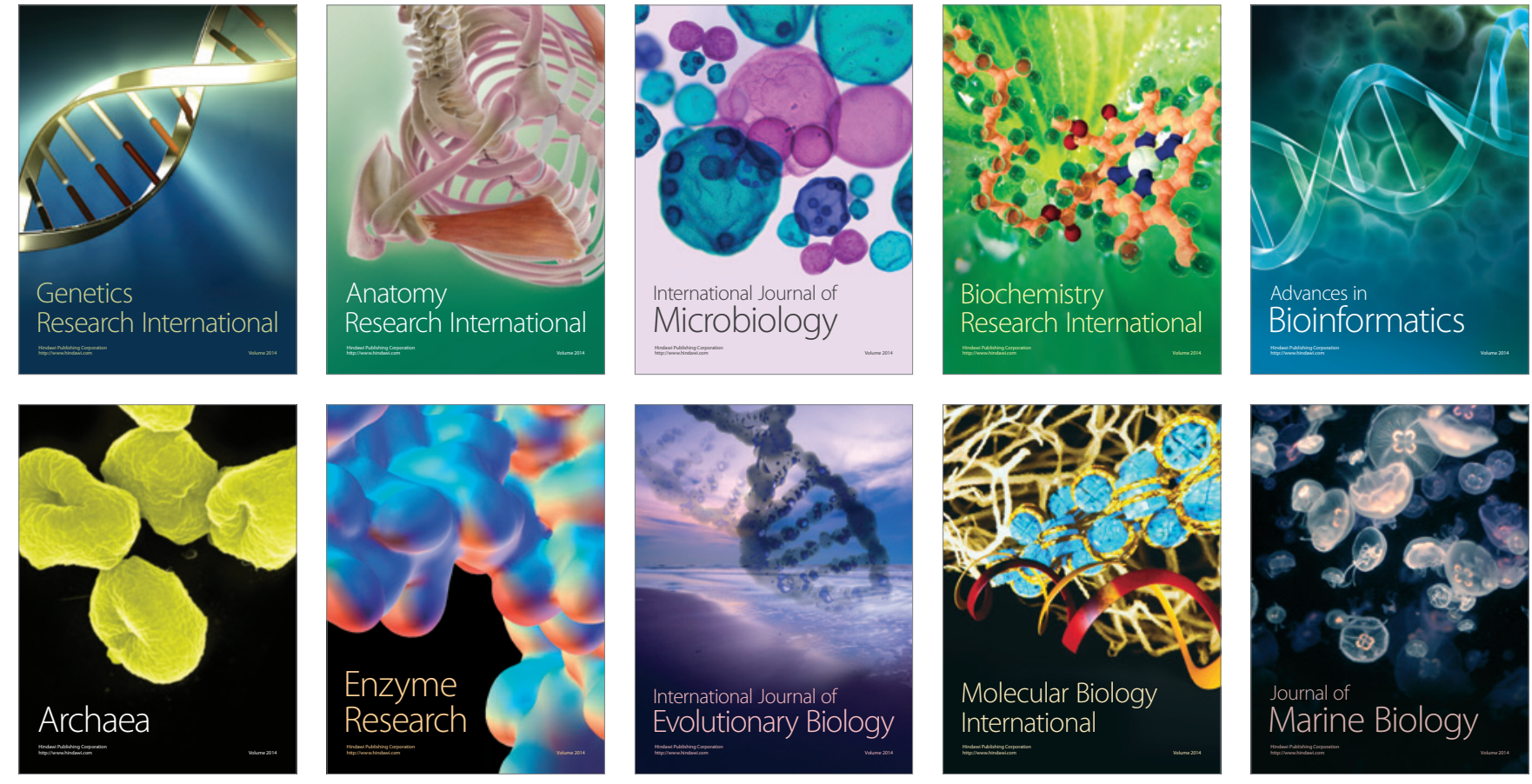